\title{
On the Distribution of Pelochelys cantorii on Borneo
}

Author(s) :Indraneil Das and Maklarin Lakim

Source: Chelonian Conservation and Biology, 5(2):323-325. 2006.

Published By: Chelonian Research Foundation

DOI: 10.2744/1071-8443(2006)5[323:OTDOPC]2.0.CO;2

URL: http://www.bioone.org/doi/full/10.2744/1071-8443\%282006\%295\%5B323\%3AOTDOPC

$\% 5 \mathrm{D} 2.0 . \mathrm{CO} \% 3 \mathrm{~B} 2$

BioOne (www.bioone.org) is a a nonprofit, online aggregation of core research in the biological, ecological, and environmental sciences. BioOne provides a sustainable online platform for over 170 journals and books published by nonprofit societies, associations, museums, institutions, and presses.

Your use of this PDF, the BioOne Web site, and all posted and associated content indicates your acceptance of BioOne's Terms of Use, available at www.bioone.org/page/terms_of_use.

Usage of BioOne content is strictly limited to personal, educational, and non-commercial use. Commercial inquiries or rights and permissions requests should be directed to the individual publisher as copyright holder. 


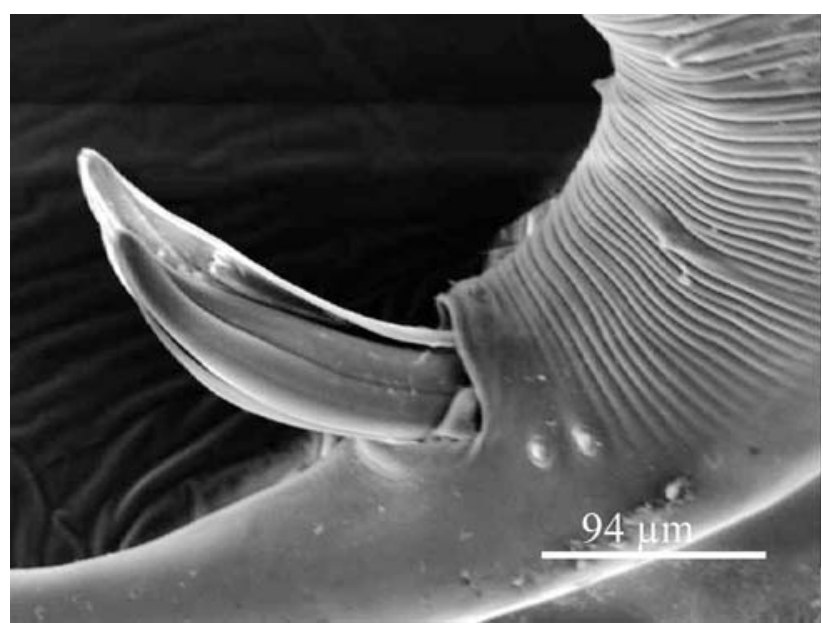

Figure 3. The morphology of Faulcaustra kutcheri nematode by SEM, magnification 350×. (Photo by E. Purwaningsih).

plantation areas (Fig. 2). The substrate in these habitats in Bangkir was generally sand, mud or occasionally rocky with vegetation consisting of grasses: Colocasia esculenta, Selaginella plana, Derris elliptica, Alocasia macrorhiza, Diplazium esculentum, and Vitis trifolia.

This study also proved that the Labonu population has been infected by the nematode Falcaustra kutcheri (Fig. 3 ), recently described by Bursey et al. (2000).

I strongly recommend that the Indonesian government offer protection to $L$. yuwonoi because it is an endemic species with a highly limited geographic distribution and is seriously threatened by habitat destruction and overexploitation due to the live animal trade. Moreover, $L$. yuwonoi has an extremely low reproductive rate with only 1 or 2 eggs per clutch, and it is difficult to maintain and breed in captivity.

Acknowledgments. - This project could not have been done without the financial support of George Saputra (Indonesian Reptiles and Amphibians Trader Association), and information on collecting localities from the collectors/traders. I thank Budiyanto Tasman (Terraria) and Fuddin Taula (Losari Depot, Palu) for assistance in the field, Nuramaliati Prijono (MZB) for the project permit, and Mumpuni Sancoyo (MZB) for the project opportunity. My special thanks to Hidetoshi Ota (University of the Ryukyus, Japan) for his editorial comments and Endang Purwaningsih for identifying the nematode.

\section{Literature Cited}

Bursey, C.R., Platt, S.G., and And Rainwater, T.R. 2000. Falcaustra kutcheri n.sp. (Nematoda: Kathlaniidae) from Leucocephalon yuwonoi (Testudines: Emydidae) from Sulawesi, Indonesia. Journal of Parasitology 86:344-349.

InNIS, C. 2003. Preliminary observations on reproductive parameters of the Sulawesi forest turtle (Leucocephalon yuwonoi) in captivity. Chelonian Conservation and Biology 4(3):720-721.
International Union For The Conservation Of Nature. 2004. 2004 IUCN Red List. http://www.iucnredlist.org.

IsKandAR, D.T. 2000. Turtles and Crocodiles of Insular Southeast Asia and New Guinea. Bandung, Indonesia: PALMedia Citra, $191 \mathrm{pp}$.

Lovich, J.E., Mittermeier, R.A., Pritchard, P.C.H., Rhodin, A.G.J., And GibBons, J.W. 2000. Powdermill Conference: trouble for the world's turtles. Turtle and Tortoise Newsletter 1:16-17.

McCord, W.P., Iverson, J.B., ANd BoEAdI 1995. A new batagurid turtle from northern Sulawesi, Indonesia. Chelonian Conservation and Biology 1(4):311-316.

McCord, W.P., Iverson, J.B., Spinks, P.Q., And Shaffer, H.B. 2000. A new genus of geoemydid turtle from Asia. Hamadryad 25(2):86-90.

Platt, S.G., Lee, R.J., and Klemens, M.W. 2001. Notes on the distribution, life history, and exploitation of turtles in Sulawesi, Indonesia, with emphasis on Indotestudo forstenii and Leucocephalon yuwonoi. Chelonian Conservation and Biology 4:154-159.

SAMEdi AND Iskandar, D.T. 2000. Freshwater turtle and tortoise conservation and utilization in Indonesia. In: van Dijk, P.P., Stuart, B.L., and Rhodin, A.G.J. (Eds.) Asian Turtle Trade: Proceedings of a Workshop on Conservation and Trade of Freshwater Turtles and Tortoises in Asia. Chelonian Research Monographs 2:106-111.

Suwelo, I.S. 1999. Turtle export. National Proceeding Conservation of Amphibian and Reptilian Biodiversity on Indonesia. Relationship PAU Biological Science Bogor Institute of Agriculture \& Reseach Centre for Biology, The Indonesian Institute of Sciences, 4 November. Bogor: Indonesia.

Yuwono, F.B. 1998. The trade of live animals in Indonesia. In: Erdelen, W. (Ed). Conservation, Trade and Sustainable Use of Lizards and Snakes in Indonesia. Mertensiella 9:9-15.

Received: 30 July 2003

Revised and Accepted: 7 June 2005

Chelonian Conservation and Biology, 2006, 5(2): 323-325 (C) 2006 Chelonian Research Foundation

\section{On the Distribution of Pelochelys cantorii on Borneo}

\section{INDRANEIL DAS $^{1}$ AND MAKLARIN LAKIM ${ }^{2}$}

${ }^{1}$ Institute of Biodiversity and Environmental Conservation, Universiti Malaysia Sarawak, 94300, Kota Samarahan, Sarawak,Malaysia [idas@ibec.unimas.my];

${ }^{2}$ Taman Negara Sabah, Box 626, Kota Kinabalu, Sabah, Malaysia [maklarin@yahoo.com]

Abstract. - Historical records for Pelochelys cantorii from Borneo are reviewed, and the first record of the species from Sabah is described.

The trionychid turtle, Pelochelys cantorii Gray, 1864, has a wide distribution, from the east and west coasts of India and coastal Bangladesh, through Myanmar, Thailand, the Malay Peninsula, Vietnam, southern China, Borneo, Sumatra, and the Philippines (Das 1995; Moll and 


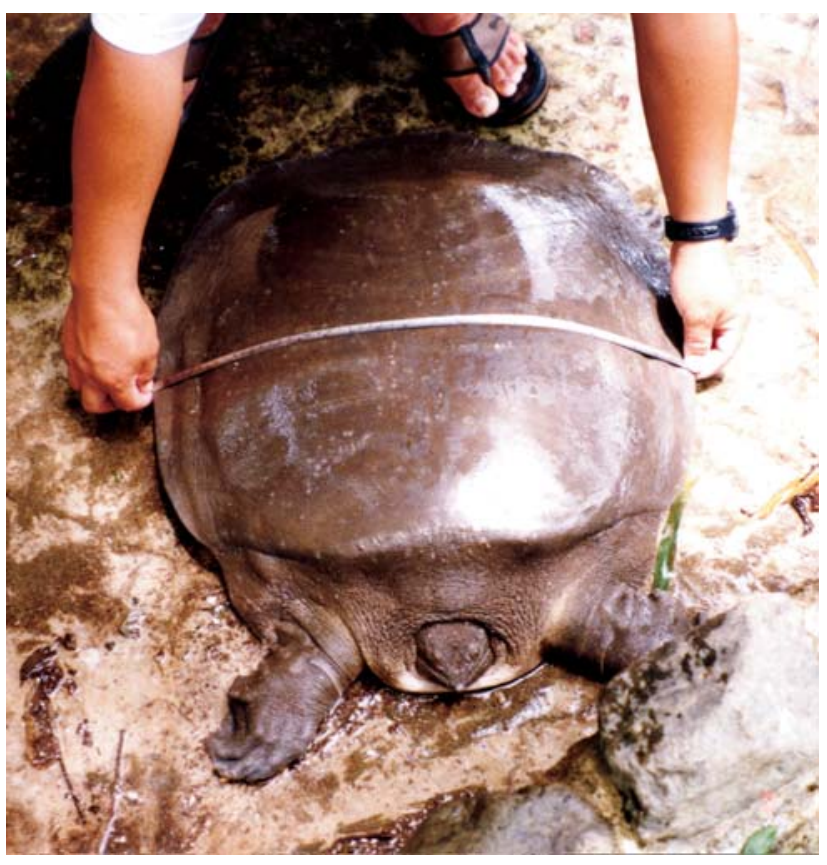

Figure 1. Adult P. cantorii from Kampung Marak Parak, Kinabalu National Park, Sabah, East Malaysia (Borneo).

Vijaya 1986; Nguyen and Ho 1996; Cox et al. 1998; Zhang et al. 1998; Iskandar 2000). The Javanese record of this species, from Tanjung Priok by Ouwens (1914) and de Rooij (1915), was shown to be based on a misidentified specimen of Chitra chitra by Iskandar (2004b), and the species is consequently removed from the fauna of Java. Many of the authors, up to the end of the 20th Century, referred to this species as Pelochelys bibroni (Owen 1853), which was restricted to New Guinea by Webb (1995, 2003).

Although this species is known from Borneo (e.g., Lim and Das 1999), only 3 records exist. One of these is "Koelei" (interpreted as Koeling by Iverson, pers. comm., corresponding with Kuling, $01^{\circ} 50^{\prime} \mathrm{S}, 112^{\circ} 55^{\prime} \mathrm{E}$, Kalimantan Tengah Province), as cited in Boulenger (1889: 263, as Pelochelys cantoris), Bartlett (1894), and de Rooij (1915: 332, also cited by Siebenrock 1909, and mapped by Iverson 1992). The spelling Koelei is here considered an error for Koetei, a colonial Dutch version of the locality name Kutai (see below). In the distribution of the species, de Rooij (1915: 332) included "Koti” (equivalent to Kutai, 00³5'S, $117^{\circ} 17^{\prime} \mathrm{E}$, Kalimantan Timur Province) within the Indonesian part of Borneo. The former locality is apparently based on a skeletonized specimen, BMNH 80.9.25.6, which would have been examined by de Rooij during the preparation of her monograph on the Indo-Australian reptile fauna. It was collected by the Norwegian explorer, Carl Bock (1849-1932), who did indeed spend time at Kutai, then an independent Malay kingdom under Dutch protection (Reese 1995) and described as “ . . . a country enjoying the worst repute among the semi-independent

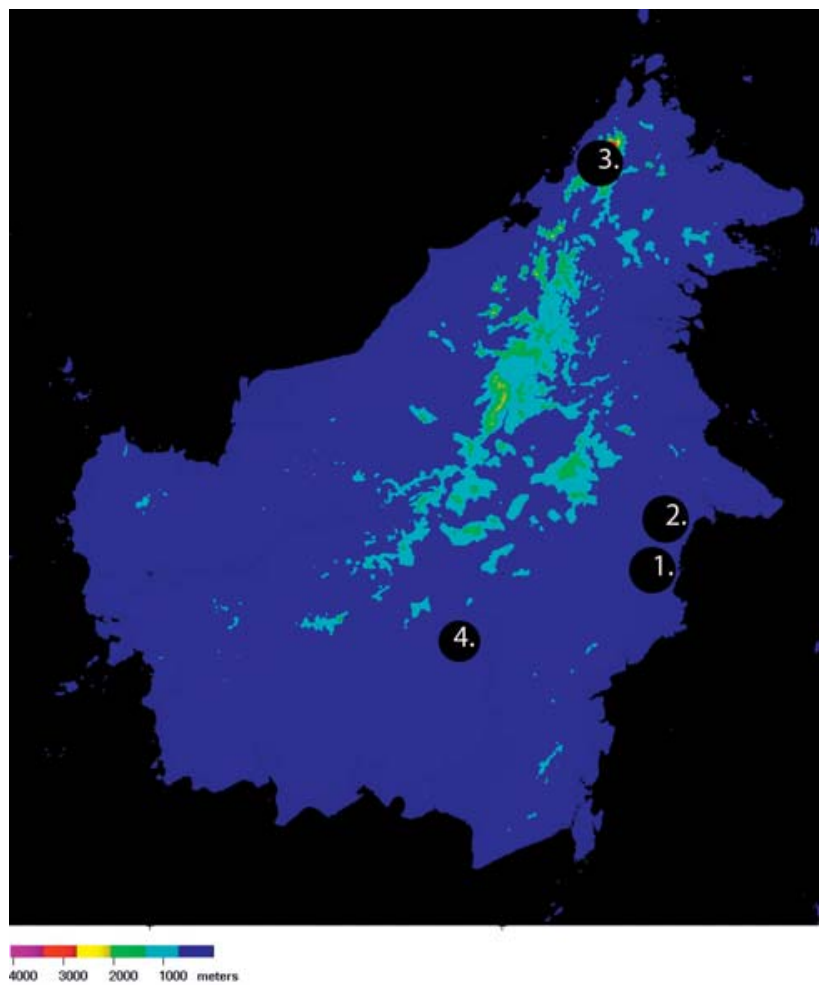

Figure 2. Map of Borneo, showing localities for P. cantorii. See text for details. References: $1=$ Kutai, Kalimantan Timur Province, Indonesia; $2=$ Sungei Berau, Kalimantan Timur Province, Indonesia; 3 = Marak Parak, Sabah, Malaysia; and $4=$ Maruwai, Kalimantan Tengah Province.

States" (Bock 1881). Bock is not known to have collected in Kalimantan Tengah (=Central Kalimantan).

Two more recent localities for $P$. cantorii from Borneo are in the literature. The first is from Sungei Berau (coordinates at mouth: $01^{\circ} 45^{\prime} \mathrm{N}, 117^{\circ} 30^{\prime} \mathrm{E}$ ), also in Kalimantan Timur Province, cited by Iskandar (2000: 90), about $40 \mathrm{~km}$ to the north of the Kutai record. The second locality is Maruwai $\left(00^{\circ} 34^{\prime} \mathrm{S}, 114^{\circ} 44^{\prime} \mathrm{E}\right)$, Kalimantan Tengah Province, and is based on a carapace (verified by ID) collected by Robert Butler Stuebing, and now accessioned with the Museum Zoologicum Bogoriense, Cibinong, Indonesia. This record has been cited by Iskandar (2004a).

We report here a fourth record of $P$. cantorii from Borneo, a specimen from Kampung Marak Parak $\left(06^{\circ} 19^{\prime} \mathrm{N}, 116^{\circ} 44^{\prime} \mathrm{E} ; 152 \mathrm{~m}\right.$ elevation), Kota Marudu District, at the edge of Gunung Kinabalu National Park, Sabah, East Malaysia (Fig. 1). The specimen was collected at the junction of Sungei Kinarom and Sungei Serimsim, within a lowland rainforest, on 30 August 2001, and accessioned with the Sabah Parks Zoological Museum, $\mathrm{SP}(\mathrm{P}) 285$. The specimen measured $644 \mathrm{~mm}$ in curved carapace length, $538 \mathrm{~mm}$ in curved carapace width, and weighed $23.0 \mathrm{~kg}$ in life.

This record represents the first published record of $P$. cantorii for Sabah, and the fourth for Borneo (Fig. 2). The 